\title{
Influence of plankton on distribution patterns of the filter-feeder Brevoortia tyrannus (Pisces: Clupeidae)
}

\author{
Kevin D. Friedland ${ }^{1}$, Dean W. Ahrenholz ${ }^{2}$, James F. Guthrie ${ }^{2}$ \\ ${ }^{1}$ National Marine Fisheries Service, Woods Hole Laboratory, Woods Hole, Massachusetts 02543, USA \\ ${ }^{2}$ National Marine Fisheries Service, Beauiort Laboratory, Beaufort, North Carolina 28516, USA
}

\begin{abstract}
Abundance of juvenile Atlantic menhaden Brevoortia tyrannus, plankton abundance, and physical data were collected concurrently along longitudinal transects in 2 estuarine creeks in North Carolina and 2 estuarine creeks in Virgina, USA, from March to August 1983. Menhaden abundance was positively correlated with abundance of microflagellates, diatoms, chlorophyll $a$, and to a limited extent dinoflagellates and cyanobacteria. Menhaden showed a distributional preference for larger (generally $>3 \mu \mathrm{m}$ in length) phytoplankton cells independent of phytoplankton taxa. Dinoflagellate blooms, which were usually composed of large cells (>16 $\mu \mathrm{m}$ in length) and had some of the highest chlorophyll a concentrations observed, were not always positively correlated with menhaden abundance. Some dinoflagellata taxa appeared to repel menhaden, whereas blooms of Prorocentrum sp. were always positively correlated with the distribution of the fish. Menhaden distribution appeared to respond to gradients of phytoplankton cells of sufficient size to be filtered by the fish, suggesting a chemosensory preference for plant rather than detrital particles and a foraging strategy patterned by the efficiency of their gill raker feeding structure.
\end{abstract}

\section{INTRODUCTION}

The time and space scales of patch size and turnover rate for phytoplankton and phytoplanktivorous fish can differ by an order of magnitude (Walsh et al. 1978, Walsh 1982). As a result, knowledge of the types of ecosystem-level correlations developed between phytoplankton and zooplankton (Beers \& Stewart 1971, Taniguchi 1973) is lacking for phytoplankton and phytoplanktivorous fish because of the difficulty in making the necessary concurrent measurements (Bainbridge 1963, Oviatt et al. 1971, Miller \& Dunn 1980). Thus, most ecosystem-level inferences for phytoplanktivorous fish are based on organism-level observations such as grazing rate experiments (Durbin \& Durbin 1975, Drenner et al. 1984, Drenner et al. 1987).

Because of their phytoplanktivorous feeding habits, juvenile Atlantic menhaden Brevoortia tyrannus (Latrobe) appear to be an ideal subject for modelling the distribution behavior of phytoplanktivorous fish in relation to phytoplankton gradients. Atlantic menhaden undergo a series of ontogenetic feeding changes du- ring larvae to juvenile and juvenile to adult transitions. The larvae, which are omnivorous plank tivores (June \& Carlson 1971, Govoni et al. 1983), undergo morphological changes in body form and feeding structure as they metamorphose into juveniles (June \& Carlson 1971) The juveniles are obligate filter-feeders and feed predominantly upon phytoplankton-sized prey (Friedland et al. 1984). As they grow, concomitant changes in their feeding structure result in a gradual shift towards including more zooplankton-sized prey (Durbin \& Durbin 1975).

Within-habitat distribution patterns of menhaden have been studied in relation to physical and planktonrelated gradients. Correlation between menhaden abundance and physical gradients of salinity and temperature has not been established despite extensive testing in the field (Massmann et al. 1954, Turner \& Johnson 1973). On the other hand, plankton-related gradients, such as turbidity and chlorophyll a concentration, have been significantly correlated with the distribution of menhaden (Kemmerer et al. 1974, Kemmerer 1980). However, these correlations are not con- 
sistent across studies since Wilkins \& Lewis (1971) found no correlation between juvenile abundance and turbidity. The hypothesis that menhaden distribution is controlled by the distribution of their food has persisted for many years (June \& Chamberlin 1959, Weinstein 1979), but has remained untested for lack of detailed observations of menraden distribution and gradients of potential food, and of laboratory experiments to test food preference.

The goal of this investigation was to identify physical and plankton-related factors correlated with menhaden abundance. Since juvenile menhaden are obligate filter-feeders, we assumed their distribution reflected feeding preferences. We recognize this field study is not a complete test of the hypothesis described above. and that other approaches, such as laboratory experiments with controlled test factors, may be necessary.

\section{MATERIALS AND METHODS}

Relative abundance of menhaden, physical data, and plankton abundance were collected along longitudinal transects (fixed station series) in 4 estuarine creeks. Bath and Hancock Creeks, located in North Carolina, USA (Fig. 1A,B), were sampled about twice a month from March to August 1983. Grays and Machodoc Creeks, located in Virginia, USA (Fig. 1C, D), were sampled about monthly from April to July 1983. These 4 creeks are relatively similar in length, with Machodoc Creek being $11.2 \mathrm{~km}$; Grays Creek, $8.8 \mathrm{~km}$; Bath Creek, $8.4 \mathrm{~km}$; and Hancock Creek, $7.8 \mathrm{~km}$. The creeks vary markedly in width, as reflected by surface area, with Bath Creek estimated to be 386 ha, Machodoc Creek 301 ha, Hancock Creek 179 ha, and Grays 78 ha Greatest recorded depths were found in Grays Creek,
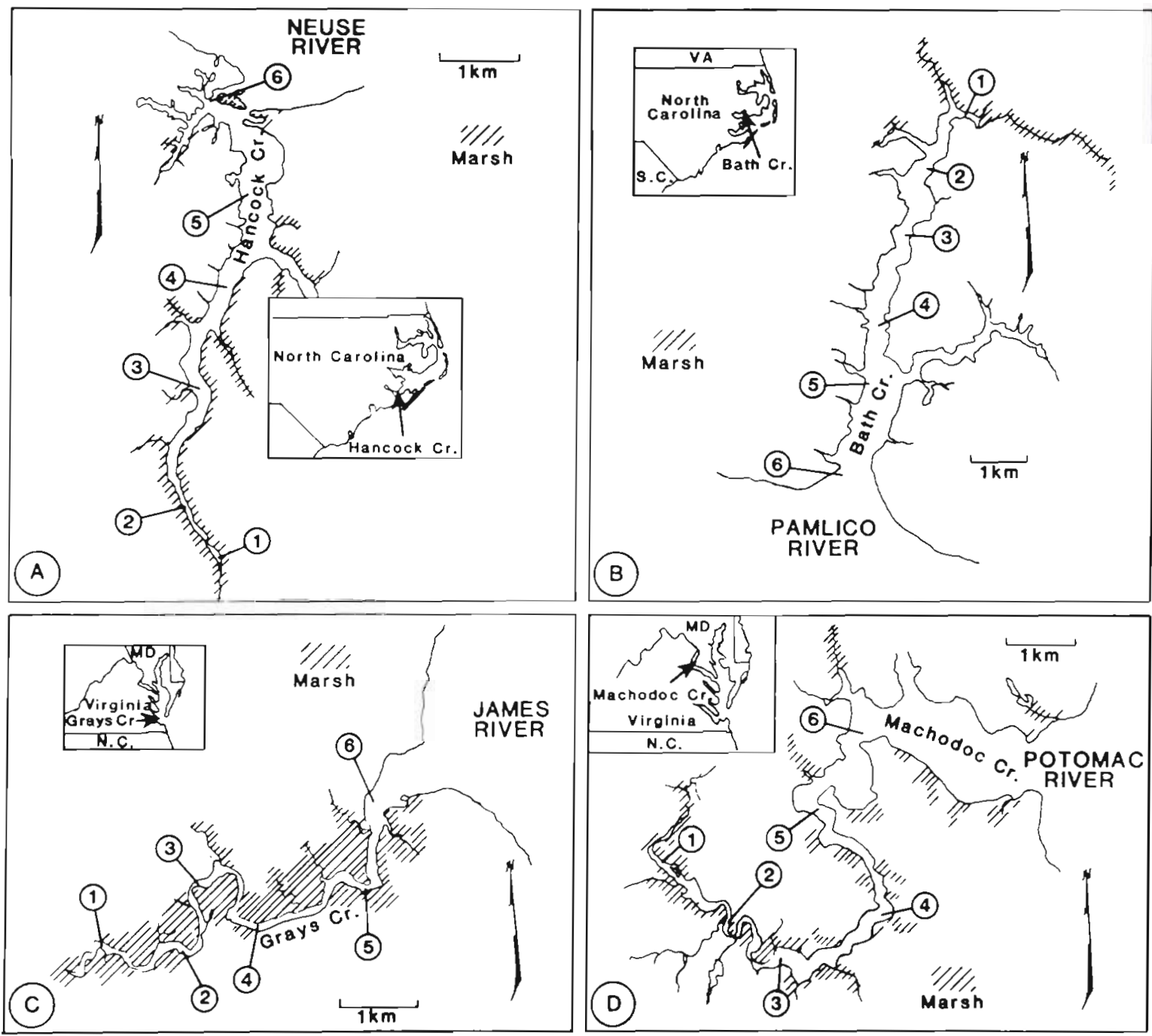

Fig. 1. Study sites with station designations. (A) Hancock Creek, North Carolina. (B) Bath Creek, North Carolina. (C) Grays Creek, Virginia. (D) Machodoc Creek, Virginia 
with some sections as deep as $7.6 \mathrm{~m}$ at mean low water. The largest continuous section of relatively deep water was in the lower portion of Bath Creek, which had depths ranging from 2.5 to $3.5 \mathrm{~m}$ over a $3.6 \mathrm{~km}$ distance. For the most part, depths ranged 1 to $2 \mathrm{~m}$ in these creeks. The North Carolina estuarine creeks are not markedly affected by lunar tides, but are subject to irregular wind-driven tidal fluctuations. The 2 Virginia estuarine creeks are subject to typical lunar tidal fluctuations.

Juvenile menhaden were sampled at each station with a single 5 min surface-trawl haul. Sampling stations were spaced at 1.5 to $2 \mathrm{~km}$ intervals over the portion of the creeks accessible to sampling with our trawl. The hauls began at pre-designated stations (Fig. 1) and proceeded downstream for ca $500 \mathrm{~m}$ as measured with flow meters. The surface trawl, measuring $6.7 \mathrm{~m}$ wide, $0.9 \mathrm{~m}$ deep at the mouth, and $6.1 \mathrm{~m}$ long, was constructed of $6 \mathrm{~mm}$ bar-length multifilament knotted nylon netting. The net was towed between 2 outboard motor boats. In a comparison of techniques for estimating the abundance of juvenile menhaden, Turner (1973) found the surface-trawl provided the most precise estimate of menhaden catch-per-uniteffort (CPUE) in creek habitats

Physical data and plankton samples were collected at the beginning of each trawl station (Fig. 1). Secchi depth was recorded to the nearest $\mathrm{cm}$. Water samples for other physical and plankton measurements were collected at a depth of $0.75 \mathrm{~m}$ with a pump sampler. Temperature was measured with a glass thermometer and salinity was determined with an Endeco refractometer (model 102). Replicate $10.0 \mathrm{ml}$ water samples were filtered through Whatman GF/F glass fiber filters at gentle pressure $\left(<3.0\right.$ psi; $2 \times 10^{3} \mathrm{~Pa}$ ) for chlorophyll a analysis. Filters were immediately preserved in a solution of dimethylsulfoxide, acetone and water at a ratio of $45: 45: 10$ with diethylamine added to $0.1 \%$. Chlorophyll a concentration, uncorrected for phaeopigment, was determined by fluorometry (D'Elia et al. 1986). A water sample for seston particle counts was collected and preserved in glutaraldehyde to a final concentrations of $0.6 \%$.

Plankton were identified and counted via epifluorescent microscopy. Two staining techniques were used to help distinguish different taxa of living cells and the origin of detrital particles. Diatoms, dinoflagellates, microflagellates, cyanobacteria, free-living bacteria and detritus were stained with proflavine hemisulfate and prepared for viewing with epifluorescent microscopy according to the methods of Haas (1982). A second stain, the brightener Calcafluor White $M 2 R$ was used to differentiate subgroups of detrital particles. Calcafluor has binding specificity for $\beta 1-4$ linked polysaccharide polymers (Hughes \& McCully 1975), which allowed optical differentiation of polymers such as cellulose, chitin, and lignin (hereafter referred to as cellulosic detritus) from proteins, lipids, and nucleic acids. Glutaraldehyde-fixed water samples stained with Calcafluor at a final concentration of $0.08 \%$ were incubated at room temperature for $24 \mathrm{~h}$, then prepared and viewed with the same methods used for the proflavine preparations (Haas 1982).

Phytoplankton cells were devided into 5 size classes for enumeration (Table 1). The longest axis of the cell body, excluding appendages such as flagella, was measured to the nearest $\mu \mathrm{m}$. Free bacteria, smaller than the smallest phytoplankton, were counted separately. Detrital particles are irregular in shape, so it was not possible to assign them to size classes. Detrital counts were based on particle equivalents of $4 \times 8 \mu \mathrm{m}$ as partitioned with an ocular grid

Pearson product-moment correlations were computed between catches and the various physical and plankton variables. Correlation coefficients were calculated for each sampling date and for pooled sampling dates for each variable. The pooled correlation was based on standard normal deviates of a transect mean (or Z-scores which equals a transect observation minus the transect mean divided by the transect standard deviation), and is taken to represent the correlation between relative CPUE and other variables.

\section{RESULTS}

Transects were made under a variety of conditions in the creeks. Ranges of physical measurements, plankton counts, and menhaden CPUE over the entire study are presented in Table 2. Salinity and temperature ranges

Table 1. Size classification of phytoplankton cells

\begin{tabular}{|lll|}
\hline Size class & Diameter $($ range, $\mu \mathrm{m})$ & \multicolumn{1}{c|}{ Taxonomic examples } \\
\hline 1 & $2-3$ & Cyanobacteria, microflagellates \\
2 & $4-7$ & Centric diatoms, microflagellates \\
3 & $8-15$ & Pennate diatoms, microflagellates \\
4 & $16-31$ & Dinoflagellates, chain-forming diatoms \\
5 & $32-63$ & Dinoflagellates, chain-forming diatoms \\
\hline
\end{tabular}


Table 2. Study range and mean transect range of juvenile menhaden Brevoortia tyrannus catch, phytoplankton counts, and physical variables. CV coefficient of variation

\begin{tabular}{|c|c|c|c|c|c|}
\hline \multirow[b]{2}{*}{ Variable } & \multicolumn{2}{|c|}{ All observations } & \multicolumn{3}{|c|}{ Transect ranges } \\
\hline & Minimum & Maximum & Mear & CV $(\%)$ & $n$ \\
\hline Salinity (\%o) & 0.0 & 10.0 & 1.9 & 89 & 24 \\
\hline Temperature $\left({ }^{\circ} \mathrm{C}\right)$ & 11.0 & 33.0 & 2.3 & 74 & 24 \\
\hline Secchi depth $(\mathrm{cm})$ & 15.0 & 90.0 & 22.0 & 61 & 24 \\
\hline Chlorophyll a ( $\mu \mathrm{g} l)$ & 1.4 & 156.0 & 33.1 & 78 & 24 \\
\hline Diatoms $\left(10^{3} \mathrm{ml}^{-1}\right)$ & 0.0 & 125.2 & 15.5 & 145 & 24 \\
\hline Dinoflagellate $\left(10^{3} \mathrm{ml}^{-1}\right)$ & 0.0 & 6.6 & 1.2 & 125 & 16 \\
\hline Microflagellate $\left(10^{3} \mathrm{ml}^{-1}\right)$ & 0.2 & 121.0 & 22.2 & 114 & 24 \\
\hline Cyanobacteria $\left(10^{3} \mathrm{ml}^{-1}\right)$ & 0.0 & 998.2 & 397.3 & 113 & 8 \\
\hline Bacterial $\left(10^{6} \mathrm{ml}^{-1}\right)$ & 1.1 & 25.0 & 4.1 & 63 & 24 \\
\hline Cellulose $\left(10^{3} \mathrm{ml}^{-1}\right)$ & 0.0 & 10.9 & 2.3 & 130 & 23 \\
\hline Detritus $\left(10^{3} \mathrm{ml}^{-1}\right)$ & 0.0 & 84.0 & 22.8 & 93 & 24 \\
\hline Size $1\left(10^{3} \mathrm{ml}^{-1}\right)$ & 0.0 & 1101.2 & 154.1 & 218 & 22 \\
\hline Size $2\left(10^{3} \mathrm{ml}^{-1}\right)$ & 0.0 & 135.7 & 22.1 & 107 & 24 \\
\hline Size $3\left(10^{3} \mathrm{ml}^{-1}\right)$ & 0.0 & 16.9 & 5.4 & 74 & 24 \\
\hline Size $4\left(10^{3} \mathrm{ml}^{-1}\right)$ & 0.0 & 11.0 & 2.3 & 117 & 21 \\
\hline Size $5\left(10^{3} \mathrm{ml}^{-1}\right)$ & 0.0 & 3.4 & 1.1 & 109 & 7 \\
\hline Total $\left(10^{3} \mathrm{ml}^{-1}\right)$ & 0.4 & 1236.5 & 158.0 & 206 & 24 \\
\hline Catch $\left(10^{3}\right.$ tow $\left.w^{-1}\right)$ & 0.0 & 27.1 & 5.4 & 113 & 24 \\
\hline
\end{tabular}

reflect the seasonal changes in temperature and flow rates from spring into summer. Minimum secchi values were encountered during high flow events and plankton blooms, as were minima and maxima of chlorophyll $a$, respectively. The taxonomic phytoplankton count categories ranges are similar to their corresponding size class counts. For example, blooms of cyanobacteria were most often scored as size class 1 phytoplankton, hence the observed similarity in their ranges of abundance. Menhaden CPUE were integrated values for all size fish. Modes of fish fork length size freqency ranged from $30 \mathrm{~mm}$, for spring and early summer transects, to $60 \mathrm{~mm}$, for middle to late summer transects.

Since the aim of the study was to test the response of juvenile menhaden to within-transect environmental gradients, the range of data in a particular transect is more important than the range over all transects. Generally, the physical factors had small gradients within a transect, whereas menhaden CPUE and phytoplankton were often concentrated at a few stations, thus creating strong gradients (reflected in coefficients of variation of transect ranges; Table 2 ).

The correlation between menhaden CPUE and physical factors were weak compared to the correlation with chlorophyll a. Correlation between CPUE and station number, where positive correlation indicated high catch associated with the station at the mouth of the creek and negative correlation indicated high catch associated with the station at the head of the creek, was significant in 11 of 24 transects, but with almost equal numbers of positive and negative correlations (Table 3). The pooled correlation coefficient, normalized by each transect, was non-significant. Correlation between CPUE and station number is the least amenable to the assumption of equivalence between creeks and must be examined in greater detail. There are sufficient samples from Hancock and Bath Creeks for examination of between-creek differences. In comparing Hancock and Bath Creeks we notice that Hancock Creek has fringing marsh vegetation through most of its course whereas in Bath Creek most of the marsh was at the creek-head. Menhaden are positively and negatively correlated with station in Hancock in approximately equal numbers of sampling dates and the pooled correlation coefficient was non-significant (0.103, $n=54, p<30.25)$. In contrast, most of the correlation coefficients between menhaden and station number were negative in Bath Creek suggesting a tendency for menhaden to congregate at the head of the creek (further supported by the pooled correlation coefficient $=-0.443, n=48, p<0.01$ ). The physical factors of salinity, temperature, and secchi depth showed no distinct positive or negative correlation trends with menhaden CPUE. In contrast, the correlation between CPUE and chlorophyll a was positive and significant in 9 transects versus only 1 negative and significant transect. In addition, the pooled correlation coefficient between chlorophyll a and catch was statistically significant.

Correlation between menhaden CPUE and various cell and particle counts revealed positive correlation with phytoplankton categories. Correlation between CPUE and diatom and microflagellate counts were positive and significant in 7 and 9 transects respec- 
Table 3. Correlation coefficients between juvenile menhaden Brevoortia tyrannus catch-per-unit-effort (CPUE) and station number, salinity, temperature, secchi depth, and chlorophyll a for individual transects. Creeks: Hancock (H), Bath (B), Machodoc $(\mathrm{M})$, and Grays $(\mathrm{G})$. Coefficients with asterisks are significant at $p<0.05(n=6)$

\begin{tabular}{|c|c|c|c|c|c|c|c|}
\hline \multicolumn{2}{|c|}{$\begin{array}{l}\text { Date } \\
\text { (1983) }\end{array}$} & \multirow{2}{*}{$\begin{array}{c}\text { Creek } \\
\text { H }\end{array}$} & \multirow{2}{*}{$\begin{array}{c}\text { CPUE } \times \\
\text { Station } \\
0.354\end{array}$} & \multirow{2}{*}{$\begin{array}{c}\text { CPUE } \times \\
\text { Salinity } \\
0.261\end{array}$} & \multirow{2}{*}{$\begin{array}{c}\text { CPUE } \times \\
\text { Temp } \\
0.369\end{array}$} & \multirow{2}{*}{$\begin{array}{c}\text { CPUE } \times \\
\text { Secchi } \\
-0.555\end{array}$} & \multirow{2}{*}{$\begin{array}{c}\text { CPUE } \times \\
\text { Chl } a \\
0.443\end{array}$} \\
\hline Маг & 4 & & & & & & \\
\hline Mar & 7 & B & -0.172 & -0.292 & 0.521 & -0.071 & -0.280 \\
\hline Mar & 28 & $\mathrm{H}$ & $0.891^{\circ}$ & $0.901^{\circ}$ & $-0.922^{\circ}$ & -0.520 & $0.780^{\circ}$ \\
\hline Mar & 30 & $\mathrm{~B}$ & -0.397 & -0.049 & 0.328 & 0.055 & -0.121 \\
\hline Apr & 7 & M & -0.266 & -0.496 & 0.676 & -0.661 & -0.719 \\
\hline Apr & 26 & $\mathrm{~B}$ & $0.874^{\circ}$ & $0.980^{\circ}$ & -0.029 & -0.087 & $0.955^{\circ}$ \\
\hline Apr & 27 & $\mathrm{G}$ & -0.740 & -0.608 & 0.746 & $0.888^{\circ}$ & $-0.803^{\circ}$ \\
\hline Apr & 28 & $M$ & $0.878^{\circ}$ & 0.680 & -0.075 & $-0.832^{\circ}$ & $0.919^{\circ}$ \\
\hline Apr & 29 & $\mathrm{H}$ & $0.928^{\circ}$ & $0.998^{\circ}$ & -0.324 & -0.608 & $0.867^{\circ}$ \\
\hline May & 13 & $\mathrm{H}$ & 0.682 & 0.578 & -0.459 & -0.413 & $0.890^{\circ}$ \\
\hline May & 18 & $\mathrm{~B}$ & -0.676 & -0.672 & $-0.808^{\circ}$ & -0.243 & -0.456 \\
\hline May & 25 & $M$ & 0.589 & $0.941^{\circ}$ & 0.163 & -0.069 & $0.920^{\circ}$ \\
\hline May & 27 & $\mathrm{H}$ & -0.105 & -0.060 & 0.128 & 0.118 & $0.969^{\circ}$ \\
\hline Jun & 2 & B & $-0.810^{\circ}$ & 0.294 & -0.605 & -0.464 & -0.151 \\
\hline Jun & 13 & $\mathrm{H}$ & $-0.858^{\circ}$ & $-0.944^{\circ}$ & $0.840^{\circ}$ & -0.103 & -0.545 \\
\hline Jun & 14 & $\mathrm{~B}$ & $-0.804^{\circ}$ & $-0.850^{\circ}$ & 0.365 & $-0.774^{\circ}$ & $0.974^{\circ}$ \\
\hline Jun & 27 & $G$ & -0.581 & -0.467 & -0.228 & 0.259 & -0.063 \\
\hline Jun & 28 & M & $0.833^{\circ}$ & $0.796^{\circ}$ & $0.892^{\circ}$ & $0.865^{\circ}$ & 0.547 \\
\hline Jun & 30 & $B$ & -0.695 & -0.413 & $-0.789^{\circ}$ & -0.652 & 0.668 \\
\hline Jul & 1 & $\mathrm{H}$ & -0.024 & -0.168 & 0.135 & 0.191 & 0.275 \\
\hline Jul & 25 & $\mathrm{H}$ & $-0.851^{\circ}$ & $-0.914^{\circ}$ & $0.906^{\circ}$ & -0.079 & -0.100 \\
\hline Jul & 26 & $\mathrm{~B}$ & $-0.864^{\circ}$ & $-0.930^{\circ}$ & $0.978^{\circ}$ & $-0.815^{\bullet}$ & 0.637 \\
\hline Jul & 28 & M & -0.598 & -0.496 & $-0.992^{\circ}$ & 0.577 & -0.437 \\
\hline Aug & 3 & $\mathrm{H}$ & $-0.914^{*}$ & $-0.899^{\circ}$ & 0.204 & -0.520 & 0.922 \\
\hline \multicolumn{3}{|c|}{ Significant positive correlations } & 5 & 5 & 4 & 2 & 9 \\
\hline \multicolumn{3}{|c|}{ Significant negative correlations } & 6 & 5 & 4 & 3 & 1 \\
\hline \multicolumn{3}{|c|}{ Normalized pooled correlation } & 0.138 & 0.077 & 0.086 & 0.188 & $0.298^{\circ}$ \\
\hline \multicolumn{3}{|l|}{$n$} & 144 & 144 & 144 & 144 & 144 \\
\hline
\end{tabular}

tively, whereas no significant negative correlations were observed (Table 4). In addition, the pooled positive correlation coefficient for these 2 categories was significant. The remaining 2 phytoplankton count categories, dinoflagellate and cyanobacteria, had low numbers of positively correlated transects. The pooled correlation coefficient between CPUE and these groups was not statistically significant. There were no trends in correlation between CPUE and bacteria, cellulosic detritus, or detritus. It was suggested above that menhaden showed no preference for any particular portion of Hancock Creek but did tend to congregate in the headwaters of Bath Creek. Though marsh vegetation was concentrated at the head of Bath Creek the pattern of correlation between menhaden and plankton for this creek is consistent with patterns observed over the whole study. For example, menhaden were poorly correlated with cellulose detritus in Bath Creek (pooled correlation coefficient $=0.113, n=48, p<0.25$ ) and strongly correlated with microflagellates (pooled correlation coefficient $=0.552, n=48, p<0.001)$. Bath Creek tended to flush at a slower rate than Hancock Creek, thus the conditions related to increased phyto- plankton production tended to occur further upstream. Further comment on factors controlling creek plankton production, such as nutrient supply and mixing, is beyond the scope of this paper.

There was a higher positive correlation between CPUE and counts of mid-size phytoplankton than with counts of the smallest or largest phytoplankton size categories. Positive correlation between CPUE and size class 1 phytoplankton was statistically significant in 5 transects, but the pooled correlation coefficient was non-significant (Table 5). Correlation between CPUE and size class 2, 3 and 4 counts were statistically significant and positive in many of the transects and all of the pooled correlation coefficients. Neither positive or negative trends emerge from the limited data for size class 5 phytoplankton. The correlation between catch and size class 2 to 4 plankton is reflected in the correlation of CPUE and total cell counts.

Menhaden tended to distribute with concentrations of larger available phytoplankton regardless of where in the transect the highest total biomass concentrations occurred. During spring transects, for example the transects of April 26 and 29, diatoms and larger micro- 
Table 4. Correlation coefficients between juvenile menhaden Brevoortia tyrannus catch-per-unit-effort (CPUE) and cell-particle counts. Creeks: Hancock (H), Bath (B), Machodoc (M), and Grays (G). Coefficients with asterisks are significant at $p<0.05(n=6)$; nd: insufficient data available to calculate coefficient

\begin{tabular}{|c|c|c|c|c|c|c|c|c|c|}
\hline \multicolumn{2}{|c|}{$\begin{array}{l}\text { Date } \\
(1983)\end{array}$} & \multirow{2}{*}{$\begin{array}{c}\text { Creek } \\
\mathrm{H}\end{array}$} & \multirow{2}{*}{$\begin{array}{l}\text { CPUE } \times \\
\text { Diatoms } \\
-0.102\end{array}$} & \multirow{2}{*}{$\begin{array}{c}\text { CPUE } \times \\
\text { Dinoflag. } \\
\text { nd }\end{array}$} & \multirow{2}{*}{$\begin{array}{c}\text { CPUE } \times \\
\text { Microflag. } \\
0.040\end{array}$} & \multirow{2}{*}{$\begin{array}{c}\text { CPUE } \times \\
\text { Cyanobac. } \\
\text { nd }\end{array}$} & \multirow{2}{*}{$\begin{array}{c}\text { CPUE } \times \\
\text { Bacteria } \\
0.439\end{array}$} & \multirow{2}{*}{$\begin{array}{l}\text { CPUE } \times \\
\text { Cellulose } \\
-0.237\end{array}$} & \multirow{2}{*}{$\begin{array}{c}\text { CPUE } \times \\
\text { Detritus } \\
0.713\end{array}$} \\
\hline Mar & 4 & & & & & & & & \\
\hline Mar & 7 & B & -0.385 & -0.166 & -0.336 & nd & 0.118 & -0.419 & 0.126 \\
\hline Mar & 28 & $\mathrm{H}$ & 0.647 & nd & 0.295 & nd & 0.750 & $-0.783^{\circ}$ & $0.895^{\circ}$ \\
\hline Mar & 30 & $\mathrm{~B}$ & -0.359 & nd & -0.188 & nd & -0.188 & 0.542 & -0.107 \\
\hline Apr & 7 & $\mathrm{M}$ & -0.450 & -0.352 & -0.233 & nd & 0.035 & -0.195 & -0.696 \\
\hline Apr & 26 & $B$ & $0.923^{\circ}$ & nd & $0.982^{\circ}$ & nd & $0.863^{\circ}$ & 0.583 & -0.694 \\
\hline $\mathrm{Apr}$ & 27 & $G$ & -0.620 & nd & -0.576 & nd & $-0.991^{\circ}$ & -0.134 & $-0.822^{\circ}$ \\
\hline Apr & 28 & $M$ & 0.578 & nd & 0.563 & nd & 0.424 & -0.368 & 0.009 \\
\hline $\mathrm{Apr}$ & 29 & $\mathrm{H}$ & $0.989^{\circ}$ & -0.393 & $0.938^{\circ}$ & nd & 0.559 & 0.667 & 0.701 \\
\hline May & 13 & $\mathrm{H}$ & $0.003^{\circ}$ & $0.985^{\circ}$ & 0.692 & nd & $0.991^{\circ}$ & $0.785^{\circ}$ & -0.497 \\
\hline May & 18 & $\mathrm{~B}$ & -0.434 & nd & $0.889^{\circ}$ & nd & 0.137 & -0.355 & 0.214 \\
\hline May & 25 & $M$ & -0.049 & -0.197 & $0.913^{\circ}$ & nd & -0.162 & -0.365 & -0.041 \\
\hline May & 27 & $\mathrm{H}$ & 0.446 & -0.452 & 0.696 & nd & -0.417 & -0.423 & $0.958^{\circ}$ \\
\hline Jun & 2 & $\mathrm{~B}$ & 0.504 & 0.729 & $0.801^{\circ}$ & $\mathrm{nd}$ & -0.687 & nd & -0.466 \\
\hline Jun & 13 & $\mathrm{H}$ & -0.329 & -0.260 & -0.764 & -0.301 & -0.698 & -0.601 & -0.500 \\
\hline Jun & 14 & $\mathrm{~B}$ & $0.887^{\circ}$ & nd & $0.937^{\circ}$ & $0.838^{\circ}$ & 0.608 & 0.287 & $0.962^{\circ}$ \\
\hline Jun & 27 & $\mathrm{G}$ & -0.568 & -0.722 & $0.763^{\circ}$ & nd & $-0.785^{\circ}$ & $0.953^{\circ}$ & $0.694^{\circ}$ \\
\hline Jun & 28 & $M$ & $0.783^{\circ}$ & 0.012 & 0.317 & 0.150 & -0.177 & 0.700 & -0.572 \\
\hline Jun & 30 & $\mathrm{~B}$ & $0.948^{\circ}$ & -0.351 & $0.995^{\circ}$ & 0.283 & 0.297 & 0.262 & -0.117 \\
\hline Jul & 1 & $\mathrm{H}$ & 0.314 & 0.351 & 0.367 & -0.659 & -0.607 & -0.318 & $0.962^{\circ}$ \\
\hline Jul & 25 & $\mathrm{H}$ & $0.894^{\circ}$ & -0.211 & -0.326 & -0.378 & 0.423 & -0.524 & -0.439 \\
\hline Jul & 26 & $\mathrm{~B}$ & $0.964^{\circ}$ & 0.416 & 0.332 & -0.489 & -0.119 & -0.108 & $0.908^{\circ}$ \\
\hline Jul & 28 & $M$ & -0.178 & -0.218 & $0.756^{\circ}$ & nd & -0.290 & 0.094 & $-0.792^{\circ}$ \\
\hline Aug & 3 & $\mathrm{H}$ & -0.208 & -0.142 & 0.256 & $0.893^{\circ}$ & -0.072 & $0.845^{\circ}$ & -0.497 \\
\hline \multicolumn{3}{|c|}{$\begin{array}{l}\text { Significant positive } \\
\text { correlations }\end{array}$} & 7 & 1 & 9 & 2 & 2 & 3 & 5 \\
\hline \multicolumn{3}{|c|}{$\begin{array}{l}\text { Significant negative } \\
\text { correlations }\end{array}$} & 0 & 0 & 0 & 0 & 2 & 1 & 2 \\
\hline \multicolumn{3}{|c|}{$\begin{array}{l}\text { Normalized pooled } \\
\text { correlation }\end{array}$} & $0.217^{\circ}$ & -0.058 & $0.381^{\circ}$ & 0.036 & 0.016 & 0.078 & 0.065 \\
\hline \multicolumn{3}{|l|}{$n$} & 144 & 96 & 144 & 48 & 144 & 138 & 144 \\
\hline
\end{tabular}

flagellates dominated the plankton communities (Fig. 2). In both cases CPUE was highly correlated with chlorophyll $a$ and those plankton size categories found in higher abundance. However, as the year progressed, the plankton communities changed and included more size class 1 phytoplankton which tended to influence the distribution of total cell counts and chlorophyll a. The highest total cell counts and chlorophyll a concentrations were not always where the highest concentrations of size 2 to 4 phytoplankton occurred. This is illustrated in 2 transects collected later in the year (June 30 and July 26). Menhaden were distributed with the gradients created by the larger size class phytoplankton regardless of where the highest total biomass concentration was (Fig. 3). These high concentrations of biomass or chlorophyll a were often size class 1 cyanobacteria, for example the July 26 transect.

Correlation between CPUE and dinoflagellate abundance was generally inconsistent, but we did observe patterns of positive and negative correlation with specific taxa. Dinoflagellates, when they did occur in bloom concentrations, were typically large cells (size class 4 and 5) and associated with high chlorophyll a levels. Dinoflagellates of the genus Porocentrum were always positively correlated with menhaden CPUE as illustrated by the transects of June 13 and July 1 (Fig. 4). But other dinoflagellate taxa, for example assemblages of Glenodinium sp. and Gyrodinium sp. on June 25 and Glenodinium sp. and Peridinium sp. on July 25, were not correlated with menhaden CPUE despite the high chlorophyll a concentrations and large cell size associated with these blooms (Fig. 5).

\section{DISCUSSION}

The distribution of juvenile menhaden appeared to respond to the distribution of phytoplankton. Within 
Table 5. Correlation coefficients between juvenile menhaden Brevoortia tyrannus catch-per-unit-effort (CPUE) and phytoplankton classified by size. Size 1 through 5 represents correlations with size class 1 through 5 phytoplankton, total represents total phytoplankton. Creeks: Hencock (H), Bath (B). Machodoc (M), and Grays (G). Coefficients with asterisks are significant at $p<0.05$ $(n=6)$, nd: insufficient data available to calculate coefficient

\begin{tabular}{|c|c|c|c|c|c|c|c|c|}
\hline \multicolumn{2}{|c|}{$\begin{array}{c}\text { Date } \\
\text { (1983) }\end{array}$} & \multirow{2}{*}{$\begin{array}{l}\text { Creek } \\
\mathrm{H}\end{array}$} & \multirow{2}{*}{$\begin{array}{c}\text { CPUE } \times \\
\text { Size } 1 \\
0.306\end{array}$} & \multirow{2}{*}{$\begin{array}{c}\text { CPUE } \times \\
\text { Size } 2 \\
0.072\end{array}$} & \multirow{2}{*}{$\begin{array}{l}\text { CPUE } \times \\
\text { Size } 3 \\
-0.110\end{array}$} & \multirow{2}{*}{$\begin{array}{c}\text { CPUE } \times \\
\text { Size } 4 \\
\text { nd }\end{array}$} & \multirow{2}{*}{$\begin{array}{c}\text { CPUE } \times \\
\text { Size } 5 \\
\text { nd }\end{array}$} & \multirow{2}{*}{$\begin{array}{c}\text { CPUE } \times \\
\text { Total } \\
0.135\end{array}$} \\
\hline Mar & 4 & & & & & & & \\
\hline Mar & 7 & $B$ & nd & -0.385 & -0.281 & $\mathrm{nd}$ & nd & -0.365 \\
\hline Mar & 28 & $\mathrm{H}$ & -0.305 & 0.679 & 0.323 & -0.343 & nd & 0.307 \\
\hline Mar & 30 & B & -0.382 & -0.130 & -0.343 & nd & nd & -0.217 \\
\hline Apr & 7 & $M$ & -0.333 & -0.126 & -0.273 & 0.352 & nd & -0.279 \\
\hline Apr & 26 & B & -0.038 & $0.907^{\circ}$ & $0.963^{\circ}$ & 0.481 & nd & 0.981 \\
\hline Apr & 27 & $\mathrm{G}$ & -0.349 & $-0.770^{\circ}$ & -0.557 & -0.077 & nd & -0.781 \\
\hline Apr & 28 & $M$ & 0.119 & 0.530 & 0.287 & 0.664 & nd & 0.586 \\
\hline $\mathrm{Apr}$ & 29 & $\mathrm{H}$ & $0.935^{\circ}$ & $0.940^{\circ}$ & $0.997^{\circ}$ & 0.526 & -0.406 & $0.959^{\circ}$ \\
\hline May & 13 & $\mathrm{H}$ & 0.509 & 0.328 & 0.646 & $0.991^{\circ}$ & nd & 0.720 \\
\hline May & 18 & $B$ & 0.200 & -0.353 & 0.512 & -0.172 & nd & -0.344 \\
\hline May & 25 & $M$ & $0.858^{\circ}$ & 0.731 & $0.874^{\circ}$ & $0.828^{\circ}$ & nd & 0.864 \\
\hline May & 27 & $\mathrm{H}$ & -0.360 & 0.592 & 0.141 & 0.698 & 0.050 & 0.579 \\
\hline Jun & 2 & $B$ & $0.845^{\circ}$ & 0.626 & 0.658 & $0.899^{\circ}$ & nd & 0.698 \\
\hline Jun & 13 & $\mathrm{H}$ & -0.336 & $-0.759^{\circ}$ & -0.240 & -0.297 & -0.381 & -0.444 \\
\hline Jun & 14 & B & $0.873^{\circ}$ & $0.884^{\circ}$ & 0.546 & $0.885^{\circ}$ & nd & $0.879^{\circ}$ \\
\hline Jun & 27 & $\mathrm{G}$ & 0.628 & -0.077 & 0.321 & 0.509 & nd & 0.316 \\
\hline Jun & 28 & $M$ & 0.056 & 0.706 & 0.681 & -0.341 & nd & $0.863^{\circ}$ \\
\hline Jun & 30 & $\mathrm{~B}$ & 0.280 & $0.997^{\circ}$ & $0.863^{\circ}$ & $0.970^{\circ}$ & nd & 0.353 \\
\hline Jul & 1 & $\mathrm{H}$ & -0.627 & 0.265 & 0.284 & 0.650 & 0.447 & -0.574 \\
\hline Jul & 25 & $\mathrm{H}$ & -0.245 & 0.062 & 0.350 & -0.211 & -0.604 & -0.183 \\
\hline Jul & 26 & $\mathrm{~B}$ & -0.494 & 0.737 & -0.317 & 0.888 & nd & -0.479 \\
\hline Jul & 28 & $M$ & nd & 0.748 & 0.191 & -0.061 & 0.249 & 0.689 \\
\hline Aug & 3 & $\mathrm{H}$ & $0.893^{\circ}$ & $0.906^{\circ}$ & -0.209 & -0.123 & $0.869^{\circ}$ & $0.894^{\circ}$ \\
\hline \multicolumn{3}{|c|}{ Significant positive correlations } & 5 & 5 & 4 & 6 & 1 & 6 \\
\hline \multicolumn{3}{|c|}{ Significant negative correlations } & 0 & 2 & 0 & 0 & 0 & 1 \\
\hline \multicolumn{3}{|c|}{ Normalized pooled correlations } & 0.138 & $0.338^{\circ}$ & $0.263^{\circ}$ & $0.335^{\circ}$ & 0.032 & $0.257^{\circ}$ \\
\hline \multicolumn{3}{|l|}{$n$} & 132 & 144 & 144 & 126 & 42 & 144 \\
\hline
\end{tabular}

obvious limitations imposed by physical and physiologic boundaries of the creek habitat (Jander 1975), menhaden appeared to orient in relation to the distribution of filterable phytoplankton food. In this context, filterable food was viewed as phytoplankton particles of sufficient size and concentration to represent a net energy gain to the menhaden in an optimal foraging context (Pyke et al. 1977). For example, smaller sized phytoplankton may form an attractive food patch if they are in higher concentrations than neighboring patches of larger phytoplankton cells. Besides the effect of phytoplankton concentration and cell size, there also appeared to be some taxa-specific avoidance of some phytoplankton by the menhaden which affected the patterns of distribution we observed.

The high correlation between menhaden abundance and phytoplankton particles and the lack of correlation with detrital particles suggested that chemical cues of odor and taste associated with phytoplankton controlled the distributional behavior of the fish. Sensory perception of the odor and taste of a food patch by menhaden was probably via extracellular exudates and surface structures of phytoplankton cells. There is strong evidence that predatory fish (Mackie 1975. Olsen et al. 1986) and herbivorous copepods (Poulet \& Ouellet 1982, George 1983, Van Alstyne 1986) begin feeding search behavior in response to amino acids in the water column. The production of extracellular exudates by phytoplankton communities is usually associated with the mature stages of a bloom (Chrost \& Faust 1983, Lancelot 1983) and include dissolved amino acids in quantities proportional to growth and biomass (Laane 1983). It is likely that phytoplankton at the study sites created chemical gradients the menhaden used to guide their food search behavior. In addition to the chemical cues from dissolved organics, the outer covering of phytoplankton cells, such as muscilagenous microfibrils, proteinaceous pellicles, thecae and periplasts (Sournia 1982), could also supply chemical cues that could be sensed by menhaden gustatory receptors (Friedland 1985).

Menhaden distribution appeared to be influenced by the cell size frequency of the plankton community. We 


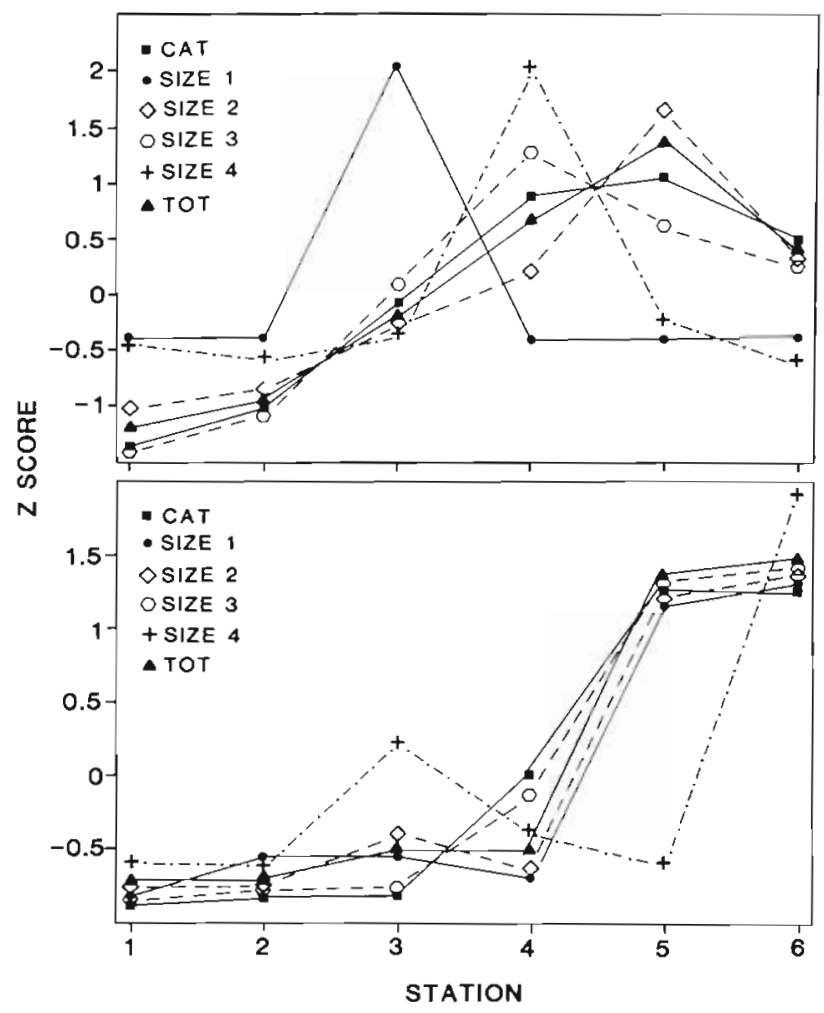

Fig. 2. Menhaden CPUE (CAT) versus size 1 to 4 (SIZE) and total (TOT) phytoplankton counts in 2 creek transects. All measurements are expressed as their $Z$-score for the transect. Upper: April 26, 1983, Bath Creek. Lower: April 29, 1983 Hancock Creek

can hypothesize 2 modalities by which menhaden determined the size of phytoplankton food. First, menhaden may have the ability to make short-term judgments on the rate of satiation relative to filtration effort. Menhaden attempting to filter small cells would not ingest large amounts of food relative to foraging effort expended, which may in turn trigger food search behavior. Second, menhaden may have a mechanoreceptive sense of gustation. Menhaden have appropriately positioned taste buds and display patterns of behavior that suggest they can sense particles in the water before beginning feeding behavior (Friedland 1985). These receptors may have the ability to differentiate particle size as well as particle concentration.

The inconsistent correlation between menhaden abundance and cyanobacteria concentrations may not be due solely to the low efficiency at which these sized phytoplankton are filtered by menhaden (Friedland et al. 1984), but instead may represent taxa-specific avoidance behavior by the menhaden. Cyanobacteria are often associated with the production of toxic (Carmichael \& Gorham 1977. Taylor 1980) and hypoxic or anoxic conditions where they bloom (Fogg 1969). Just as chemical sensory cues could have mediated the

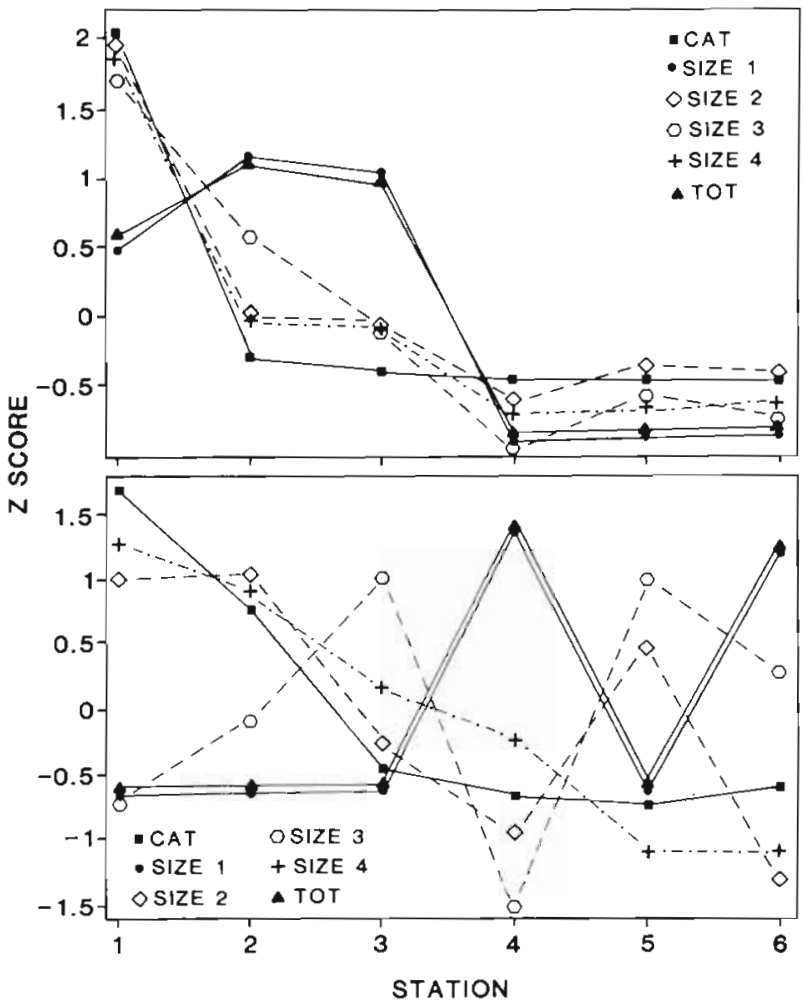

Fig. 3. Menhaden CPUE (CAT) versus size 1 to 4 (SIZE) and total (TOT) phytoplankton counts in 2 creek transects. All measurements are expressed as their $Z$-score for the transect. Upper: June 30, 1983, Bath Creek. Lower: July 26, 1983, Batch Creek

attraction of menhaden to phytoplankton foods, they may have also elicited avoidance behavior by the menhaden to potentially noxious conditions created by some taxa of cyanobacteria.

Specific taxa of dinoflagellates, which were of ideal size and concentration for menhaden to feed upon, were either avoided by the menhaden or themselves avoided predation. The only dinoflagellate taxa with which the menhaden were consistently distributed were members of the genus Prorocentrum. Other dinoflagellate taxa, which were poorly correlated with menhaden abundance, may have produced chemical cues that elicited avoidance behavior by the menhaden (Ukeles \& Sweeny 1969, Mahoney \& Steimle 1979, White 1980, 1981, Horstman 1981). Alternatively, because dinoflagellates are highly mobile, it is possible they avoided grazing by menhaden by completing a vertical migration in a time frame shorter than the food search times of the fish (Blasco 1978, Horstmann 1980, Tyler \& Seliger 1981).

Though our observations were not dynamic they do add to our understanding of menhaden chemo-orientation. We would assert that menhaden employ klinokinesic chemo-orientation, where the intensity of 


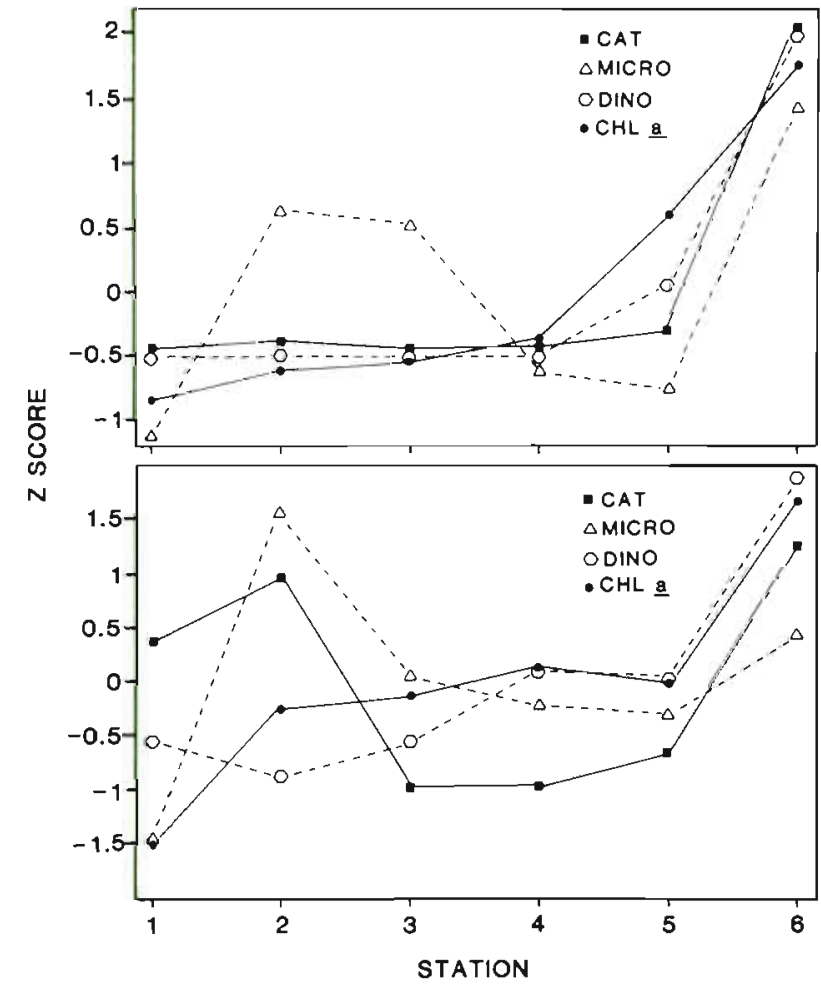

Fig.4. Menhaden CPUE (CAT) versus microflagellate (MICRO) and dinoflagellate (DINO) phytoplankton counts and chlorophyll a (CHL a) measurements in 2 creek transects. All measurements are expressed as their $Z$-score for the transect. Upper: June 13, 1983 Hancock Creek. Lower: July 1 1983, Hancock Creek

the chemical stimulus modulates the turning rate and angular velocity of locomotion (Fraenkel \& Gunn 1961), to locate food patches. This assertion is based upon the repeated pattern of linearity between menhaden and phytoplankton abundance (Fig. 1), which we are interpreting as a direct stimuli-response relationship. Additionally, menhaden swimming habits would dictate this type of kinesis over others since they are unlikely to stop swimming during daylight hours. But, we also agree with Bell \& Tobin (1982) that simple classification does not facilitate cross-phyletic comparisons and does not define the actual mechanism at work. They proposed a chemo-orientation classification scheme which is useful as a framework for understanding orientation mechanisms with menhaden. By their definition, a chemo-orientation is functionally defined by (1) the sensory information available, (2) the sensory information processing, (3) motor output responses, and (4) the nature of the guidance system. Chemical sensory information correlated with phytoplankton is abundant in the water column (item 1) and menhaden are capable of both taste and smell (item 2). But, menhaden food search patterns are not known and would require

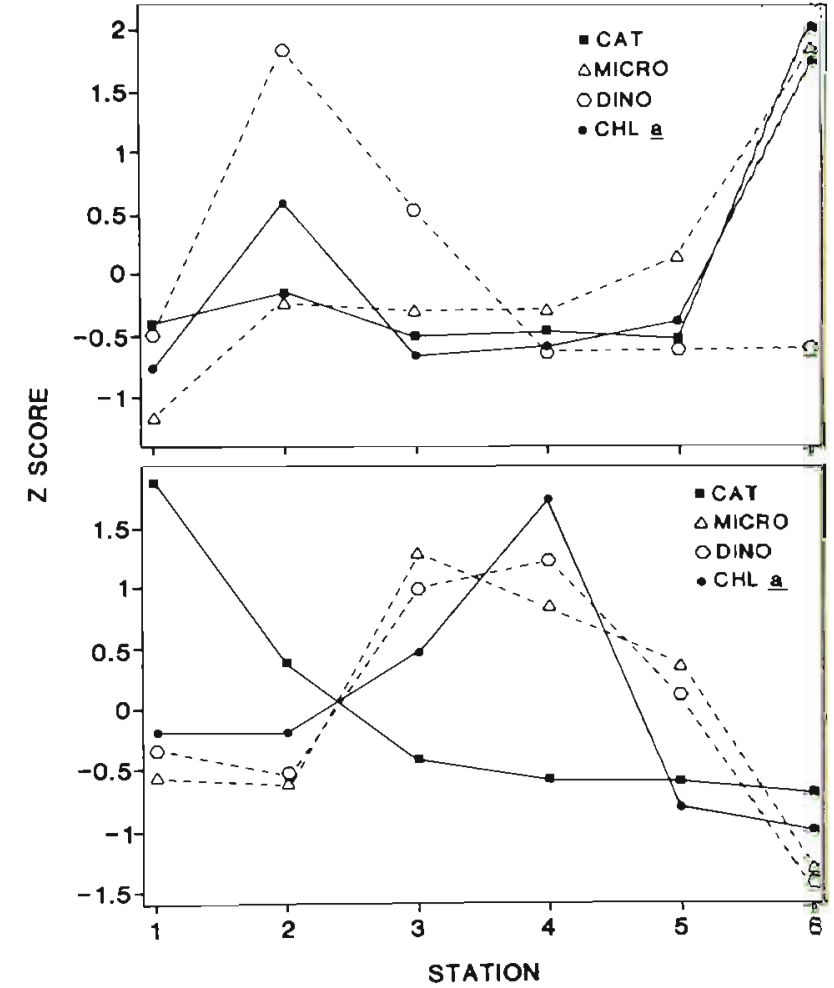

Fig. 5. Menhaden CPUE (CAT) versus microflagellate (MICRO) and dinoflagellate (DINO) phytoplankton count and chlorophyll a (CHL a) measurements in 2 creek tsansects All measurements are expressed as their $Z$-score for the transect. Upper: June 25, 1983 Machodoc Creek. Lower: July 25 1983, Hancock Creek

further research, especially in relation to plankton gradients (item 3). Finally, the nature of the guidance system in menhaden will be a synthesis of existing information and proposed research described above (item 4).

Distribution patterns of menhaden revealed the patch choice aspect of the species' optimal foraging strategy. Menhaden appeared to select food patches to maximize phytoplankton biomass consumption based upon criteria of prey size and concentration in the same manner other predators select larger and more concentrated prey patches (Werner \& Mittelbach 1981 Belovsky 1986). Combining the 2 selection criteria suggests that the motivating force for patch choice selection was the availability of filterable biomass, with filtration efficiency being analogous to handling time of higher predators. Mechanisms by which menhaden further adjusted their diet through patch choice would reflect attractiveness and edibility of food items and reveal how hunger and sensory modalities interact to create observed food preferences (Nicotri 1980). For example, if the correlation is stronger between menhaden abundance and microflagellates versus diatoms, it 
may in part be because of higher plasma volumes for equivalent sized cells for microflagellates (Strathmann 1967).

The role of menhaden in pelagic food webs has been difficult to assess due to the problems of estimating their grazing impact on the plankton community. Since menhaden occur in large numbers and have the ability to filter large amounts of water it has been suggested they may have an important effect on energy flow and nutrient regeneration (McHugh 1967, Oviatt et al. 1971). In addition to their potential effect on patterns of primary production, menhaden are recognized as an important forage species for secondary and tertiary predators (Oviatt 1977). In the limited geographic context of Narragansett Bay, the impact of menhaden grazing on primary production was considered minimal (Kremer \& Nixon 1978). However, because these workers only considered large adult menhaden, their conclusions are not directly applicable to estimating the potential grazing impact in other parts of their range. The correlation between menhaden abundance and gradients of preferred food confers a level of predictability to menhaden distribution and residence. With synoptic characterization of phytoplankton, for example by remote sensing, in situ menhaden abundance measurements could be expanded to ecosystem-wide estimates of residence and grazing. The role of phytoplanktivorous fish in estuarine and coastal ecosystems, which has been difficult to describe because of the differences in time and space scales of patch size and turnover rate of phytoplankton and phytoplanktivorous fish, may be more accurately defined.

Acknowledgements. We thank R. Clayton, H. Gordy, M. Cox and J. Merriner for their help in this study.

\section{LITERATURE CITED}

Bainbridge, V. (1963). The food, feeding habits and distribution of the bonga Ethmalosa dorsalis (Culvier and Valenciennes). J. Cons, int. Explor Mer. 28: 270-284

Beers, J. R., Stewart, G. L. (1971). Micro-zooplankters in the plankton communities of the upper waters of the eastem tropical Pacific. Deep Sea Res. 18: 861-883

Bell, W. J., Tobin, T R. (1982). Chemo-orientation. Biol. Rev. $47 \cdot 219-260$

Belovsky, G. E. (1986). Generalist herbivore foraging and its role in competitive interactions. Am. Zool. 26: 51-69

Blasco, D (1978). Observations on the diel migration of marine dinoflagellates off the Baja California coast. Mar Biol. 46: $41-47$

Carmichael. W W. Gorham, P. R. (1977). Factors influencing the toxicity and animal susceptibility of Anabaena flosaquae (Cyanophyta) blooms. J. Phycol. 13: 97-101

Chrost, R. HI., Faust, M. A. (1983). Organic carbon release by phytoplankton: its composition and utilization by bacterioplanktoro. J. Plankton Res. 5: 477-493

D'Elia, C. E., Webb, K. L., Shaw, D. V., Keefe, C. W. (1986).
Methodological comparisons for nitrogen and chlorophyll determinations in estuarine water samples. Chesapeake Biological Laboratories, Solomons, Maryland, Reference no. UMCEES-CBL-86-55

Drenner, R. W., Hambright, K. D., Vinyard, G. L., Gophen, M., Pollingher, U. (1987). Experimental study of size-selective phytoplankton grazing by a filter-feeding cichlid and the cichlid's effects on plankton community structure. Limnol. Oceanogr. 32: 1138-1144

Drenner, R. W., Mummert, J. R., de Noyelles, F., Kettle, D (1984). Selective particle ingestion by a filter-feeding fish and its impact on phytoplankton community structure. Limnol. Oceanogr 29: 941-948

Durbin, A. G., Durbin, E. G. (1975). Grazing rates of the Atlantic menhaden Brevoortia tyrannus as a function of particle size and concentration. Mar Biol. 33: 265-277

Fogg, G. E. (1969). The physiology of an algal nuisance. Proc. R. Soc. 173: 175-189

Fraenkel, G. S., Gunn, D. L. (1961). The orientation of animals Oxford University Press, New York

Friedland, K. D. (1985). Functional morphology of the branchial basket structures associated with feeding in the Atlantic menhaden, Brevoortia tyrannus (Pisces: Clupeidae). Copeia 1985 (4): 1018-1927

Friedland, K. D., Haas, L. W., Merriner, J. V. (1984). Filtering rates of the juvenile Atlantic menhaden Brevoortia tyrannus (Pisces: Clupeidae), with consideration of the effects of detritus and swimming speed. Mar. Biol. 84: 109-117

George, D. G. (1983). Interrelations between the vertical distribution of Daphnia and chlorophyll $a$ in two large limnetic enclosures. J. Plankton Res. 5: 457-475

Govoni, J. J., Hoss, D. E., Chester, A. J. (1983). Comparative feeding of three species of larval fishes in the Northern Gulf of Mexico: Brevoortia patronus, Lejostomus xanthurus, and Micropogonias undulatus. Mar Ecol. Prog. Ser 13: 189-199

Haas, L. W. (1982). Improved epiflourescence microscopy for observing planktonic micro-organisms. Annls Inst océanogr., Paris 58: 261-266

Horstman, D. A. (1981). Reported red-water outbreaks and their effects on fauna of the west and south coasts of South Africa, 1959-1980. Fish. Bull. S. Afr. 15: 71-88

Horstmann, U. (1980). Observations on the peculiar diurnal migration of a red tide dinophyceae in tropical shallow waters. J. Phycol. 16: 481-485

Hughes, J., McCully, M. E. (1975). The use of an optical brightener in the study of plant structure. Stain Tech. 50: 319-329

Jander, R. (1975). Ecological aspects of spatial orientation. A. Rev. Ecol. Syst. 6: 171-188

June, F. C., Carlson, F. T. (1971). Food of young Atlantic Menhaden, Brevoortia tyrannus, in relation to metamorphosis. Fish. Bull. U.S. 68: 493-512

June, F. C., Chamberlin, J. L. (1959). The role of the estuary in the life history and biology of Atlantic Menhaden. Proc. Gulf Caribb. Fish. Inst., 11th Ann. Sess.: 41-45

Kremer, J. N., Nixon, S. W. (1978). A coastal marine ecosystem. Springer-Verlag, New York

Kemmerer, A. J. (1980). Environmental preferences and behavior patterns of gulf menhaden (Brevoortia patronus) inferred from fishing and remotely sensed data. In: Bardach, J. E., Magnuson, J. J., May, R. C., Reinhart, J. M. (eds.) Fish behavior and its uses in the capture and culture of fishes. ICLARM Conference Proceedings, Vol.5. International Center for Living Aquatic Resources Management, Manila, Philippines, p. 345-370

Kemmerer, A. J., Benigno, J. A., Reese, G. B., Minkler, F. C. 
(1974). Summary of selected early results from the ERTS-1 menhaden experiment. Fish. Bull. U. S. 72: 375-389

Laane, R. W P. M. (1983). Seasonal distribution of dissolved and particulate amino acids in the Ems-Dollart estuary. Oceanologica Acta 6: 105-109

Lancelot, C. (1983). Factors affecting phytoplankton extracellular release in the Southern Bight of the North Sea. Mar Ecol. Prog. Ser 12: 115-121

Mackie, A. M. (1975). Chemoreception. In: Malins, D. C., Sargent, J. R. (eds.) Biochemical and biophysical perspectives in marine biology. Academic Press, New York, p. 69-105

Mahoney, J. B., Steimle, F. W (1979). A mass mortality of marine animals associated with a bloom of Ceratium tripos in the New York bight. p. 225-230. In: Taylor, D. L.., Selinger, H. H. (eds.) Toxic dinoflagellates blooms. Elsevier, Amsterdam, p. 225-230

Massmann, W. H., Ladd, E. C., McCutcheon, H. N. (1954). Postlarvae and young of the menhaden (Brevoortia tyranus) in brackish and fresh waters of Virginia. Copeia 1954: 19-23

McHugh, J. L. (1967). Estuarine nekton. In: Lauff, G. H. (ed.) Estuaries. American Association for the Advancement of Science, Washington, p. 581-620

Miller, J. M. Dunn, M. L. (1980). Feeding strategies and patterns of movement in juvenile estuarine fishes. In: Kennedy, V S. (ed.) Estuarine perspectives. Academic Press, New York, p. $437-448$

Nicotri, M. E. (1980). Factors involved in herbivore food preference. J. exp. mar Biol. Ecol. 42: 13-26

Olsen, K. H., Karlsson, L., Helander, A. (1986). Food search behavior in arctic charr, Salvelinus alpinus (L.), induced by food extracts and amino acids. J. chem. Ecol. 12: $1987-1988$

Oviatt, C. A. (1977). Menhaden, sport fish, and fishermen. University of Rhode Island, Mar. Tech. Rep. 60

Oviatt, C. A., Gall, A. L., Nixon, S. W (1971). Environmental effects of Atlantic menhaden on surrounding waters. Chesapeake Sci. 13: 321-323

Poulet, S. A., Ouellet, G. (1982). The role of amino acids in the chemosensory swarming and feeding of marine copepods. J. Plankton Res. 4: 341-361

Pyke, G. H., Pulliam, H. R., Charnov, E. L. (1977). Optimal foraging: a selective review of theory and tests. Q. Rev. Biol. 52: $137-154$

Sournia, A. (1982). Form and function in marine phytoplankton. Biol. Rev. 57 347-394

Strathmann, R. R. (1967). Estimating the organic carbon con-

This article was presented by Dr G.W. Thayer, Beaufort, N. Carolina, USA tent of phytoplankton from cell volume or plasma volume Limnol. Oceanogr. 12: 411-418

Taniguchi, A. (1973)., Phytoplankton-zooplankton relationships in the Western Pacific Ocean and adjacent seas. Mar Biol. 21. 115-121

Taylor, F. J. R. (1980). Basic biological features of phytoplankton cells. In: Morris, I. (ed.) The physiological ecology of phytoplankton. Univ of California Press, Berkeley

Tyler, M. A., Seliger, H. H. (1981). Selection for a red tide organism: physiological responses to the physical environment. Limnol. Oceanogr 26: 310-324

Turner, W. R. (1973). Estimating year class strength of juvenile menhaden. In: Pacheco, A. L. (ed.) Proceedings of a workshop on egg, larval, and juvenile stages of fish in Atlantic coast estuaries. U.S. Dept. Comm. NOAA, NMFS, Mid. Atl. Coast. Fish. Center. Tech Pub. No. 1, p. 37-46

Turner, W. R., Johnson, G. N. (1973). Distribution and relative abundance of fishes in Newport River, North Carolina. NOAA Technical Report NMFS SSRF-666

Ukeles, R., Sweeney, B. M. (1969). Influence of dinoflagellate trichocysts and other factors on the feeding of Crossostea virginica larvae on Monochrysis lutheri. Limnol. Oceanogr 14: 403-410

Van Alstyne, K. L. (1986). Effects of phytoplankton taste and smell on feeding behavior of the copepod Centropages hamatus. Mar Ecol. Prog. Ser. 34: 187-190

Walsh, J. J. (1982). The marine resources experiment program MAREX. NASA, Goddard Space Flight Center

Walsh, J. J., Whitledge, T E., Barvenik, F. W., Wirick, C. D., Howe, S. O. (1978). Wind events and food chain dynamics within the New York Bight. Limnol. Oceanogr. 23: 659-683

Weinstein, M. P. (1979). Shallow marsh habitats as primary nurseries for fishes and shellfish, Cape Fear River, North Carolina. Fish. Bull. U. S. 77 : 339-357

Werner, E. E., Mittelbach, G. G. (1981). Optimal foraging: field tests of diet choice and habitat switching. A.m. Zool. 21: $813-829$

White, A. W (1980). Recurrence of kills of Atlantic herring (Clupea harengus harengus) caused by dinoflagellate toxins transferred through herbivorous zooplankton. Can. J Fish. Aquat. Sci. 37: 2262-2265

White, A. W. (1981). Sensitivity of marine fishes to toxins from the red-tide dinoflagellate Gonyaulax excavata and implications for fish kills. Mar. Biol. 65: 255-260

Wilkins, E. P. H., Lewis, R. H. (1971). Abundance and distribution of young Atlantic menhaden. Brevoortia tyrannus, in the White Oak Estuary, North Carolina. Fish. Bull. U. S. 69: $783-789$

Manuscript first received: August 20, 1988

Revised version accepted: February 23, 1989 